\title{
NBN wt Allele
}

National Cancer Institute

\section{Source}

National Cancer Institute. NBN wt Allele. NCI Thesaurus. Code C50999.

Human NBN wild-type allele is located within $8 \mathrm{q} 21$ and is approximately $51 \mathrm{~kb}$ in length.

This allele, which encodes nibrin protein, is involved in DNA double-strand break repair and

DNA damage-induced checkpoint activation. Functional mutations in the NBN gene produce allelic variants that are involved in Nijmegen breakage syndrome. 